\title{
Challenges and Opportunities for Small and Medium Enterprises in Eastern Indonesia in Facing the COVID-19 Pandemic and the New Normal Era
}

\author{
Andri Irawan a 1 \\ ${ }^{a}$ University of Yapis Papua, Jayapura, Indonesia
}

\begin{abstract}
APA Citation:
Irawan, A. (2020). Challenges and opportunities for small and medium enterprises in eastern indonesia in facing the covid-19 pandemic and the new normal era. TIJAB (The International Journal of Applied Business), 4(2), 79-89.

Submission Date: 08/10/2020

Acceptance Date: $07 / 11 / 2020$
\end{abstract}

\begin{abstract}
Eastern Indonesia is one of the areas affected by COVID-19 pandemic. Small and Medium Enterprises (SMEs) such as; culinary businesses are the business sector most affected by this pandemic, where the implementation of social restrictions has resulted in decreased income and also changes in business patterns. This condition certainly provides new challenges and opportunities for SMEs owners. The purpose of this study is to explore the challenges and opportunities of SMEs in eastern Indonesia during the COVID-19 pandemic and the new normal era. The study method uses a qualitative approach with an exploratory strategy. The results of the study found that to face the new normal era, SMEs have challenges such as the ability of human resources, understanding of information technology, and business model transformation. An interesting finding in this study is that in facing the new normal era, information technology is not a determining factor for increasing consumer trust and increasing income, but product hygiene and environmental sanitation are the determining factors for the existence of SMEs in eastern Indonesia.
\end{abstract}

Keywords: COVID-19 pandemic, small and medium enterprises, new normal era, hygiene and sanitation.

\section{Introduction}

The new normal era or a condition where humans have to change their life patterns during the COVID-19 pandemic cause all activities must have restrictions such as social distancing, restrictions on socio-economic activities aimed at avoiding the transmission of this virus. However, these restrictions will certainly have an impact on the economic and social life of the community. In addition, with the existence of this pandemic, the habits of the community in Eastern Indonesia tend to have changed, the community is more careful in meeting their daily needs, both primary needs such as food and secondary needs such as clothing, when in normal condition (before the pandemic), the community conducts activities without being limited by health protocols, the fulfilment of primary and secondary needs is

\footnotetext{
${ }^{1}$ Corresponding author.

E-mail address: andriirawan@uniyap.ac.id
} 
mostly carried out through direct transactions but now the situation has changed, COVID-19 has created social construction and also new business changes for small and medium enterprises (SMEs) where new business practices do not only promoting information technology as a strategy of competitive advantage, but the guarantee of safety and health protection, product hygiene, and environmental sanitation are the main demands for SME practices. This uncertain situation forces humans to adapt to new conditions, that we have to behave normally in the pandemic era (New Normal Life era). We must continue our activities by meeting health standards and self-protection procedures as an effort to prevent the spread of COVID-19. The COVID-19 pandemic has forced countries in the world to create preventive scenarios, such as regional quarantine and social restrictions. This pandemic has destroyed the health sector and the economy globally (Bong et al., 2020).

\section{Literature Review}

Ahlstrom et al. (2020) states that the environment and new normal life will have an impact on business practices and methods, for that the role of the leaders of the organization or the owner of small and medium-sized businesses must prepare the power both through information technology and other strategies, COVID-19 does not just have an impact on the health sector as stated by Zeegen, Yates, \& Jevsevar (2020) in which many hospitals have decreased income and increased expenditure due to handling COVID-19 in the United States so researchers ask whether we will return to normal situations or face new normality after COVID-19. Of course, the impact is clearly more widespread in other sectors such as economy, politics, and security. To that end, the ability of leaders is very important in facing the new normal life at this time where business practices will certainly be changed and will have an impact on the marketing process, production and sales as well (Postavaru, Draghici, Filip, Mohammed, \& Mohammed, 2020). Furthermore, to improve business performance, owners of the small and medium business must have entrepreneurial knowledge and abilities as well as strategic agility that will support their business performance (Widjajani \& Nurjaman, 2020). Moreover, Small and Medium Enterprises must have an assessment of their business performance, have a business performance evaluation matrix that is applied regularly to ensure business growth (Mahmudova, 2018). Small and medium businesses must carry out open innovations such as understanding the desires of customers who put the commercial aspects into perspective, in addition to product innovations are also important to do, as an important note that small and medium businesses have very limited funding so the innovations carried out must be in accordance with its business goals (Khan \& Arshad, 2019). However, to face the challenges of new normality besides information technology support, business organizations need personnel supports, then new normality will be a challenge to find alternative solutions for the organization's existence. Therefore, the business owners need to make a training plan for their personnel that will support the development of their competitive advantage strategy (Peshkova, Kiselev, \& Zimina, 2020). In addition, if the company wants to recruit, the new normality of the recruitment system through social media is the right solution, even though Jacobson \& Gruzd (2020) states that most applicants who use social media do not feel comfortable due to the revealed personal information on social media and can be seen by the public. However, current information technology advances view that personal information is very difficult to be protected, especially in new normalities we must begin to learn to accept it, however, the company must still be committed to protect the personal data of their personnel and consumer from crime. Cybercrime is the biggest threat to small and medium businesses that implement e-business today, the mistake they have made is that they consider small-scale e-business to be very safe from cybercrime threats, they consider that such crimes are only committed to bigger business entities, such thinking makes a great opportunity for the perpetrators of crime to damage the e-business of small and medium businesses (Bulletin et al., 2017). 
Restrictions on activity and physical distancing are now a global trend, the COVID-19 pandemic has not yet ended, physical distancing will certainly become a new trend in new normality after the pandemic ends and this will certainly affect many aspects such as health, social, and economic aspects in new normal life. Even more stringent scenarios are conveyed by Cannistraci \& Capua (2020) which states that social interventions on population demographics in new normality are certainly needed in which elderly people are more vulnerable to the risk of death compared to younger ages. This is certainly an important note for stakeholders to carry out social interventions in the form of legal regulations or policies that restrict activities for the elderly. Buheji \& Ahmed (2020) state that the impact of COVID 19 will clearly provide opportunities and challenges or negative and positive effects on social and economic conditions, there will be many changes in life before and after the COVID-19 pandemic, hidden opportunities and challenges are certainly important to be explored through studies. Furthermore, study on the opportunities and challenges of COVID-19 in socio-economic conditions has been carried out by Mustajab et al. (2020) who state that the impact of COVID-19 has forced many organizations to force their employees to work from home, this condition has provided opportunities and challenges for business organizations, including SMEs. There are some positive impacts of work from home such as flexibility in working, work life balance, quality of time with family, meanwhile the negative impacts are the amount of social distraction and decreased work motivation because working from home is not a culture for many organizations.

There are many evidences that small and medium-sized businesses contribute to the national economy, although the role of small and medium-sized businesses still has obstacles that must be resolved such as the readiness of human resources, infrastructure and capital such as the results of studies conducted by Eniola \& Entebang (2015) and Tanasić, Janjić, \& Kosec (2020). Thus, to maintain the existence of small and medium enterprises in the midst of threats that risk bringing down their business, however the role of government is needed through interventions that have a positive impact on SMEs so that they can overcome these challenges if access to capital is open to them and clear legal protections as conveyed by Mottaeva \& Gritsuk (2017), Halunko, Halunko, \& Savyuk (2019) who have agreed that the closeness between the government as a regulator and SME entrepreneurs will be able to stimulate the growth of SMEs, the development of information and communication technology should be done by the government to support the growth of SMEs and also the legal certainty that must be created as a form of protection for SMEs. Perception about changes in the industry in the current technological era, all SMEs in the world almost experience similar problems like the problem of human resource capabilities and also the entrepreneurial knowledge they have is still considered to be inadequate. Besides, high economic growth is generally expected by all countries, but on the other hand, it can pose risks to the development of small and medium-sized businesses because economic growth can trigger inflation which impacts on people's purchasing power, therefore small and medium-sized businesses have the greatest risk to be affected (Kristanti, Rahayu, \& Isynuwardhana, 2019).

The results of previous studies, see Leick (2020), and see also Kurniawati, Al Siddiq, \& Idris (2020) have revealed a lot about what challenges SMEs must overcome to maintain their business, and what opportunities do SMEs have? However, the results of studies reveal more about the need for information technology and also the role of government to save SMEs from the threats of business failure. It should be underlined that previous study findings may only apply to normal situations (before the pandemic), the question is are the research findings still relevant for SMEs in facing the new normal life era that will take place? The appeal of this study is in the results of exploration challenges and new opportunities for small and medium enterprises in a pandemic situation. Facing the New Era of Normal Life will give you a new perspective and a new paradigm for the study in the future, where information and technology of communications is not the most significant factor for business survival. The determining factor for 
the resilience of SMEs in the New Normal era is the assurance of product hygiene from the production process to marketing and sanitation of the business environment.

\section{Method}

The study method used is qualitative study with an exploratory strategy that aims to obtain an explanation and description of the study problem as an initial finding that forms the basis for further studies (John W. Creswell, 2014). Study informants were selected using purposive sampling by determining the criteria of SMEs in the culinary field who have been in business for more than 3 years. The reasons for choosing these criteria are because SMEs in Eastern Indonesia is more dominated by the culinary sector and are the sectors most affected by the COVID-19 pandemic.

\subsection{Sample / Participants}

Interviews were conducted with 10 informants in Jayapura who are owners of traditional culinary businesses, 5 informants from Makassar and also 5 people from Palu who are culinary business owners who have used social media to market their business. The consumers we randomly interviewed are regular consumers of the 20 participating culinary business owners.

\subsection{Data collection procedures}

Data collection was carried out by applying the COVID-19 protocols, which was done virtually through video calls and Zoom Cloud Meeting with an average duration of interviews for 1.5 hours, questions were given in an unstructured manner which aimed to dig deeper into the data and information needed. Data analysis was carried out using the help of the qualitative data analysis software of NVivo 12 plus so that data management and analysis were more accurate. This study was conducted for 2 months starting from April to May 2020. Besides, we also conducted interviews with 20 consumers who were customers at SMEs that became the informant in this study.

\section{Results}

Based on interviews conducted with 10 informants in Jayapura who are owners of traditional culinary businesses, 5 informants from Makassar and also 5 people from Palu are culinary business owners who have used social media for marketing their business. The consumers we interviewed randomly were regular consumers of the 20 culinary business owners who were informants, this study has succeeded in constructing the basic concept of challenges and opportunities for SMEs in Eastern Indonesia as initial findings that will be a reference for further studies, challenges and opportunities for SMEs in Eastern Indonesia can be described as follows:

\subsection{Challenge for SMEs}

\subsubsection{Scarcity of additional raw materials}

Most SMEs in Eastern Indonesia said that during the pandemic and large-scale social restrictions were implemented resulting in the scarcity of additional raw materials due to delays in supply from Java island, this is because most of the additional raw materials needed by SMEs in eastern Indonesia is still supplied from Java Island. The highest dependency is felt mostly by SMEs in Ternate and Jayapura, therefore many SMEs are limiting the amount of production and implementing a pre-order system to consumers as a strategy to maintain their business operations while waiting for the supply of additional raw materials.

The first participant from Papua stated; 
Restrictions of transportation operation and operational on goods delivery services have resulted in a scarcity of raw materials, especially raw materials that we have obtained from outside the island of Java instant of; certain brands of wheat flour, pasta, and other ingredients. So, in this situation, we are induced to limit the amount of production in order to be able to maintain business operations until the supply of raw materials back to normal.

The continuance process of production can be maintained by maintaining the continuity of raw materials. Proper and efficient management of raw material can reduce costs due to errors in the ordering and storage of raw materials. Mistakes in managing raw materials also cause expenses for workers' wages and delay the production process (Lubis, 2017).

\subsubsection{Product hygiene guarantee and environmental sanitation}

The most important factor and a major challenge in the culinary business when the COVID-19 pandemic is the hygienic guarantee of products sold starting from the selection of quality raw materials that are free of hazardous chemicals such as pesticides or formalin and production standards are really supervised by business owners. This is conducted to provide assurance to consumers and bring back their trust that their products are safe for consumption. Many SMEs actors document their production processes ranging from selecting raw materials to packaging products in video format, this strategy is considered to be very effective in providing understanding to customers that cleanliness, health, and safety of the products they sell are absolutely guaranteed. Furthermore, the business environment sanitation factor, SMEs in Eastern Indonesia agree that sanitation is also a key factor to bring back consumer trust during the COVID-19 pandemic, besides product hygiene and health, environmental hygiene will be an indicator for consumers to choose where they will determine the choice that they consider to be very safe and protected from the transmission of COVID-19, the strategy undertaken by SMEs is to reorganize their business place according to the COVID-19 protocol which is to provide a place to wash hands with running water and hand washing soap, regulate spacing tables and chairs so that consumers do not sit close to other consumers and require all employees and consumers to wear masks. Some SMEs in Jayapura have even submitted certificates from the local government as a guarantee to consumers that their culinary business and business place are truly hygienic and their sanitation is guaranteed so that they are safe from the threat of COVID-19 transmission because they have followed the health protocols.

The third participant from Palu stated;

To assure consumers that the products we sell are clean, healthy and safe for consumption, we make short videos about how we process the products we sell, starting from selecting raw materials, processing, packaging to how we market them. That is very important for us to do wherein the current situation, many consumers have doubts about the cleanliness and health of the culinary business.

The use of digital technology in maintaining the sustainability of micro, small, medium enterprises (MSMEs) is crucial and cannot be avoided. Increasing acrimonious and dynamic competition accompanied by shifting in consumer behavior due to digitalization requires businesses to be adaptive. MSMEs must also be able to make reliable marketing communications, both in the content of the messages conveyed and the forms of communication chosen in order to generate demand and sales, and also get a response from consumers (Sulistyo, 2019).

\subsubsection{Consumer trust}

SMEs actors state that consumer trust is the most difficult factor to obtain. Extra efforts are needed by SME actors such as maintaining communication with consumers through social media, sending videos of processing products with health standards and hygienic and provide special offers for them such as price discounts or adding items at fixed prices (buy one get one). SME actors realize that changes in consumer behavior and trust are not caused by the low quality of the food or products they sell, but rather the fear of transmission of COVID-19 so that consumers prefer to stay at home or process their 
own food which is considered safer. Strategies such as maintaining communication with consumers have proven to be very effective, through short videos sent via social media and WhatsApp messages to gradually bring back consumer trust, in this case, SME actors also consider it very important to provide educational videos about the transmission of COVID-19 both to SME actors and consumers about the transmission and prevention patterns of COVID-19 to provide a comprehensive understanding.

She also stated;

However, we have to think the strategy to get through from this situation, that there are many of our consumers chose to reduce their consumption of food from our outlets, and then they chose to cook for their families by themselves for their safety and health. Therefore, we try to convince our consumers by sending short videos that we make from processing raw materials to marketing standards that we set through social media such as WhatsApp. Most important, we have to keep up the communication with our customers to maintain their trust and confidence. That our products are healthy, clean, hygienic, and at the same time, we provide information about the COVID-19 health protocol.

Social media marketing communications greatly influence consumer cognitive, affective, and behavioural responses. The interaction of consumers with social media produces a positive attitude response and will increase their confidence toward the offered products (Duffett, 2017).

\subsubsection{Change in consumer service}

Social distancing and also physical distancing have become an obstacle for the culinary business in the SME sector in Eastern Indonesia, they generally change consumer services following health protocols established by the government. Social distancing and physical distancing cause consumers to be reluctant to go to outlets or restaurants and enjoy food directly on the spot, this forces SME actors to change the service system into a delivery order, although currently in Eastern Indonesia, applicationbased online delivery and purchase services are available, such as gojek and grab, the additional costs to be incurred by consumers are sometimes more expensive than the products they buy so applicationbased services are not a priority choice for consumers, demands for maximum service to the consumer absolutely must be given by the SME actors, for that most of them provide additional services, i.e. direct delivery to their respective addresses without additional costs with the terms agreed upon. Besides, changes in service also occur in the transaction system, which is initially carried out more by the direct payment method, during the COVID-19 pandemic, almost all SME actors implement online payment systems such as transfers or via debit and credit, as well as the ordering service system for all SME actors in Eastern Indonesia that became informants have stated that almost $85 \%$ of bookings were made through social media such as Facebook and Instagram. This is caused by the suggestion to work from home and restrictions on social activities recommended by their respective local governments so that if consumers want to buy food from outside, they prefer ordering online via Facebook, WhatsApp, or Instagram managed by SMEs rather than through application-based online services.

\subsubsection{The ability of personnel}

Changes in service and hygiene guarantee and product sanitation will certainly have an impact on the ability of personnel or employees and leaders of SMEs. The SME actors stated that they must learn how to manage social media for business purposes and how to produce food products with hygiene and apply environmental sanitation patterns. This condition is a new challenge for them, even though before the pandemic they understood that information, communication, and technology (ICT) have developed in the business and SME fields, the current conditions, according to them, are very different. All SME actors stated that they gained knowledge about social media management and hygienic product management procedures they got through online learning via YouTube and by asking people who understood and practiced it in advance. They argued that the process of learning through YouTube and asking directly to more experienced people makes it easier for them to increase their knowledge and 
abilities so that SME actors do not need to do special education and training for their employees to improve the ability of personnel following their business needs.

\subsection{Opportunities for SMEs}

\subsubsection{Product development}

With the social restrictions and demands on hygiene products and environmental sanitation, the business of consumers, many SME actors do product development such as the development of frozen food or semi/half-cooked food products. The development of this product is considered more practical and safer for consumption and more attractive to consumers because they assume that in frozen food, no bacteria can survive in freezing temperatures so it is safe for consumption. Also, SME actors innovate in packaging their products, including information about food expiration time, processing information and this has been proven to have increased their income and bring back consumer trust in SME's processed products.

The second participant from Makassar stated;

Our strategy in dealing with the current situation is to develop products as alternative options for our customers, such as frozen food. Many of our customers believe that neither bacteria nor viruses will be able to survive in cold temperatures, so we seize these opportunities and develop our products according to customer wishes. The frozen food products that we produce gave information about the production date and expired period so that customers are more confident of our products have health standards and are safe for consumption according to the product description on the package.

COVID-19 is a challenge for culinary business owners. Social distancing, the reduction of people movement, forced culinary business owners to choose strategies in processing, packaging, marketing, and food preservation during the COVID-19 pandemic (Ginanneschi \& Srl, 2020).

\subsubsection{Creating a hygiene and healthy service system}

The service system before the pandemic has now been abandoned by SME actors, the service system has implemented health protocols ranging from the production process, product packaging, marketing, and sales. SME actors require all employees to use personal protective equipment such as masks, transparent face masks, and gloves so that both consumers and employees are truly protected from the threat of COVID-19 transmission. In addition, services in business places require consumers to meet established health protocols if they want to consume food or dishes sold directly in their places, such as washing their hands, washing their faces and enjoying their dishes in a place that has been set apart. Consumers cannot choose the place according to their desire as usual when the service before the pandemic. Even some SMEs in Jayapura have adopted more selective standards that require consumers who come directly to enjoy their food by showing the results of an official rapid test from a referral hospital. This is carried out because the SMEs do feel they must take responsibility and feel obliged to be directly involved in overcoming this COVID-19 outbreak which clearly has an impact on many sectors including the SME sector so that by changing the hygienic and healthy service system will maintain the existence of SMEs in the midst of the pandemic while at the same time involved directly in fighting against the spread of COVID-19.

\subsubsection{Business system transformation}

The overall change process carried out by SMEs in Eastern Indonesia has caused a significant change in the business system, this is done to maintain its existence in a situation that has threatened its business so far. However, the strategies chosen by SMEs are deemed appropriate strategies to adapt to new circumstances that they have never experienced, even though there are risks that they may have to accept but those risks are not commensurate with larger threats such as loss of consumer trust that will have an impact on greater losses. Business system changes made by SME actors mostly focus on service 
systems, transaction systems and production systems that prioritize health protocols and the use of information and communication technology that before the pandemic period did not apply to their businesses.

\subsubsection{Creating competitive advantage strategy}

The strategies that have been taken by SMEs in Eastern Indonesia directly and unwittingly have become competitive advantage strategies during the pandemic, creativity, and innovation such as promotion, product hygiene guarantee and environmental sanitation and service systems that pay attention to health protocols will be an advantage for SMEs who have successfully transformed their businesses in the midst of the current pandemic. By choosing a superior strategy, the SME actors are very confident that their business will continue to run even develop amid the threat of the pandemic and they will get used to a new life that will change many aspects of life, including the culinary business they have today.

The threat of a COVID-19 pandemic to the existence and development of SME businesses in Eastern Indonesia has clearly changed its business system from production, distribution, marketing to sales. However, SMEs are an important pillar of economic growth in Eastern Indonesia. Geographical conditions and also inequality in infrastructure development lead to limited access and expensiveness of transportation to and from Eastern Indonesia, and this has an impact on how often SME actors face the scarcity of additional raw materials such as cooking spices, cooking oil, flour, rice and other raw materials which until now still depend on Java island so that sometimes it can stop production and sales at their businesses. Dar, Ahmed, \& Raziq (2017) state that the obstacles that are often found as obstacles to small and medium businesses are the rules or regulations issued by the government and the availability of raw materials. Thus, the presence of both central and local governments that give priority to supply logistics for SMEs, especially during the pandemic, massive distribution of logistics carried out by the government at this time is more on direct assistance to the affected people even though it is a priority but the actions and policies taken should be balanced between humanitarian assistance and stimulus assistance to support the economic growth of SMEs.

Creativity and innovation amid this pandemic are very important to be carried out by SMEs which is a strategy to bring back consumer trust. The role of social media has now proven to be the most effective marketing tool. Shyam (2018) concludes that social media has provided opportunities for entrepreneurs and consumers to interact and transact, social media has been proven to help small and medium-sized businesses to be able to develop their business through applications and websites that support the spread of business effectively and efficiently. Regardless of this opinion, however, at present in pandemic conditions and welcoming the New Normal era, it is not only social media and information technology that support the existence of SMEs to overcome all challenges and create new business opportunities, but the most important factor for SME businesses today is also how SMEs are capable of transforming the business strategies that implement stringent health protocols supported by utilization of information and communication technology and health technology such as digital body temperature measuring devices to bring back consumer trust in products produced by SMEs, especially in the culinary field in Eastern Indonesia. In facing the new normal era, SMEs clearly have been demanded to continue to improve their business performance through enhancing the skills of their personnel and leadership through the experience of others and through independent learning media that have proven capable of providing knowledge or knowledge transfer as it has been done by SME actors in Eastern Indonesia, this is in line with the theory of Bandura (1986) about social learning theory. 


\section{Conclusions}

It can be concluded that the COVID-19 pandemic has created threats, challenges, and opportunities for SMEs in Eastern Indonesia, the existence of SMEs depends on the extent to which they can overcome the existing challenges and how their strategies are so that they can carry out the safest business transformation during the pandemic. The role of information and communication technology (ICT) in the current situation serves only as a supporting factor. The main factors of the current strength of SMEs are the hygiene factors of the products and sanitation of the business environment and health protocols that are applied both to employees and consumers so that the level of consumer trust and SME personnel will be well established which will have an impact on SME growth and the readiness, especially for SMEs in Eastern Indonesia in facing the COVID-19 pandemic and welcoming as well as adapting in the New Normal era.

However, this study has limitations such as the limited area coverage which is only taken in 3 cities located in Eastern Indonesia as well as data collection techniques that are carried out virtually with a time limit. Therefore, further studies are expected to be carried out more longitudinally so that it will contribute more broadly both theoretically and practically, especially to the problems of Small and Medium Enterprises (SMEs) in Indonesia.

\section{References}

Ahlstrom, D., Arregle, J. L., Hitt, M. A., Qian, G., Ma, X., \& Faems, D. (2020). Managing Technological, Sociopolitical, and Institutional Change in the New Normal. Journal of Management Studies, 57(3), 411-437. https://doi.org/10.1111/joms.12569

Bandura, A. (1986). Social foundations of thought and action: A cognitive social theory. New York: Pretince Hall.

Bong, C. L., Brasher, C., Chikumba, E., McDougall, R., Mellin-Olsen, J., \& Enright, A. (2020). The COVID-19 Pandemic: Effects on Low and Middle-Income Countries. Anesthesia and Analgesia, XXX(Xxx). https://doi.org/10.1213/ANE.0000000000004846

Buheji, M., \& Ahmed, D. (2020). Planning for "The New Normal": Foresight and Management of the Possibilities of Socio-economic Spillovers due to COVID-19 Pandemic. Business Management and Strategy, 11(1), 160. https://doi.org/10.5296/bms.v11i1.17044

Bulletin, S., Sciences, E., Etaec, S. I., Polkowski, Z., Dysarz, J., \& Affairs, D. (2017). It Security Management in Small and Medium Enterprises. Buletin Ştiinţific: Universitatea Din Piteşti. Seria Ştiinţe Economice, 16(3), 134-148.

Cannistraci, C. V., \& Capua, I. (2020). Age-adaptive and gender-balanced social interventions might be stepping stones to the next ne normal in COVID-19 outbreak. (May). https://doi.org/10.20944/preprints202005.0005.v1

Dar, M. S., Ahmed, S., \& Raziq, A. (2017). Small and medium-size enterprises in Pakistan: definition and critical issues. Pakistan Business Review, (April 2017), 46-70. Retrieved from http://journals.iobmresearch.com/index.php/PBR/article/view/1245

Duffett, R. G. (2017). Influence of social media marketing communications on young consumers' attitudes. Young Consumers, 18(1), 19-39. https://doi.org/10.1108/YC-07-2016-00622 
Eniola, A. A., \& Entebang, H. (2015). Government Policy and Performance of Small and Medium Business Management. International Journal of Academic Research in Business and Social Sciences, 5(2). https://doi.org/10.6007/ijarbss/v5-i2/1481

Ginanneschi, M., \& Srl, F. F. (2020). The Future of Food After Covid-19 Through the Lens of Anthropology. Retrieved from https://www.researchgate.net/publication/343493119

Halunko, V., Halunko, V., \& Savyuk, M. (2019). Foreign Experience for Financing Small and Medium Business. Baltic Journal of Economic Studies, 4(5), 40. https://doi.org/10.30525/2256-0742/20184-5-40-45

Jacobson, J., \& Gruzd, A. (2020). Cybervetting job applicants on social media: the new normal? Ethics and Information Technology. https://doi.org/10.1007/s10676-020-09526-2

John W. Creswell. (2014). RESEARCH DESIGN Pendekatan Kualitatif, Kuantitatif dan Mixed (IV). Yogyakarta: PUSTAKA BELAJAR.

KHAN, Y. K., \& Arshad, A. S. M. (2019). Innovation Ecosystem in the Small and Medium Enterprises. Journal of Management Info, 6(1), 51-54. https://doi.org/10.31580/jmi.v6i1.461

Kristanti, F. T., Rahayu, S., \& Isynuwardhana, D. (2019). The survival of small and medium business. Polish Journal of Management Studies, 20(2), 311-321. https://doi.org/10.17512/pjms.2019.20.2.26

Kurniawati, E., Al Siddiq, I. H., \& Idris. (2020). E-commerce opportunities in the 4.0 era innovative entrepreneurship management development. Polish Journal of Management Studies, 21(1), 199210. https://doi.org/10.17512/pjms.2020.21.1.15

Leick, T. M. \& B. (2020). Locational challenges and opportunities for SMEs in border regions. European $\begin{array}{lll}\text { Planning Studies, } & \text { 28(10), 2078-2098. }\end{array}$ https://doi.org/https://doi.org/10.1080/09654313.2019.1705765

Lubis, N. (2017). Analisis Pengendalian Bahan Baku Pada UMKM Kampoeng Cookies and Rotte Di Pekanbaru Riau. Jurnal Daya Saing, 3(2), 148-154. https://doi.org/10.35446/dayasaing.v3i2.99

Mahmudova, L. (2018). Definitining the Performance of Small and Medium Enterprises. Network Intelligence Studies, 6(12), 111-120.

Mottaeva, A., \& Gritsuk, N. (2017). Development of infrastructure of support of small and medium business. MATEC Web of Conferences, 106. https://doi.org/10.1051/matecconf/201710608083

Mustajab, D., Bauw, A., Rasyid, A., Irawan, A., Akbar, M. A., \& Hamid, M. A. (2020). Working from Home Phenomenon as an Effort to Prevent COVID-19 Attacks and Its Impacts on Work Productivity. The Internationa Journal of Applied Business, 53(9), 1689-1699. https://doi.org/10.1017/CBO9781107415324.004

Peshkova, G. Y., Kiselev, S. V., \& Zimina, I. V. (2020). Personnel support for innovative economic development in the new normality. Journal of Physics: Conference Series, 1515(5). https://doi.org/10.1088/1742-6596/1515/5/052074

Postavaru, N., Draghici, G., Filip, C., Mohammed, A.-R., \& Mohammed, S. M. (2020). Business Management Strategies for Business Development. Organization of the Territory and Planning of Construction Works. Ovidius University Annals of Constanta - Series Civil Engineering, 21(1), 45-50. https://doi.org/10.2478/ouacsce-2019-0005 
Shyam, R. (2018). Impact of Social Media Marketing in Small and Medium Business. AMBER - ABBS Management Business and Entrepreneurship Review, 9(1), 50. https://doi.org/10.23874/amber/2018/v9/11/176060

Sulistyo, V. R. \& A. P. (2019). Efektifitas Komunikasi Pemasaran Pada Usaha Mikro, Kecil dan Menengah Bidang Kuliner di Surabaya. Keuangan Dan BIsnis. https://doi.org/10.32524/jkb.v17i1.494

Tanasić, Z., Janjić, G., \& Kosec, B. (2020). Lean Concept in Small and Medium Enterprises. Materials and Geoenvironment, 66(2), 129-137. https://doi.org/10.2478/rmzmag-2019-0010

Widjajani, \& Nurjaman, R. (2020). The Framework of Strategic Agility in Small and Medium Enterprise. Journal of Physics: Conference Series, 1477(5). https://doi.org/10.1088/1742$6596 / 1477 / 5 / 052034$

Zeegen, E. N., Yates, A. J., \& Jevsevar, D. S. (2020). After the COVID-19 Pandemic: Returning to Normalcy or Returning to a New Normal? Journal of Arthroplasty, 1-5. https://doi.org/10.1016/j.arth.2020.04.040

Tantangan dan Peluang Usaha Kecil Menengah di Indonesia Timur Menghadapi Pandemi COVID-19 dan Era Normal Baru

\begin{abstract}
Abstrak
Kawasan Timur Indonesia merupakan salah satu wilayah yang terdampak pandemi COVID-19. Usaha Kecil Menengah (UKM) merupakan sektor usaha yang paling banyak terkena dampak pandemi ini dimana penerapan pembatasan sosial telah mengakibatkan penurunan pendapatan dan juga perubahan pola usaha, kondisi ini tentunya memberikan tantangan dan peluang baru bagi pelaku UMKM. Tujuan penelitian ini adalah untuk menggali tantangan dan peluang UKM di kawasan timur Indonesia pada saat pandemi COVID-19 dan era normal baru. Metode penelitian menggunakan pendekatan kualitatif dengan strategi eksplorasi. Hasil penelitian menemukan bahwa dalam menghadapi era new normal, UKM memiliki tantangan seperti kemampuan sumber daya manusia, pemahaman teknologi informasi, dan transformasi model bisnis. Temuan yang menarik dalam penelitian ini adalah dalam menghadapi era normal baru, teknologi informasi bukanlah faktor penentu untuk meningkatkan kepercayaan konsumen dan meningkatkan pendapatan, tetapi kebersihan produk dan sanitasi lingkungan menjadi faktor penentu keberadaan UKM di kawasan timur Indonesia.
\end{abstract}

Kata kunci: pandemi COVID-19, usaha kecil dan menengah, era normal baru, higienis dan sanitasi 